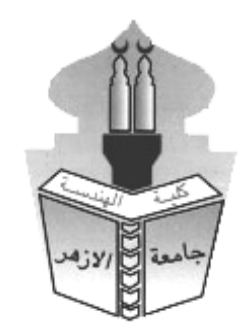

\title{
TREATMENT OF PAPER INDUSTRY WASTEWATER
}

\author{
H. A. Attia ${ }^{1}$, M. G. Farghaly ${ }^{1}$, A. M. Ramadan', A.M. Saleh ${ }^{2}$, M. A. Abdel Khalek \\ ${ }^{1}$ Mining and Petroleum Dept., Faculty of Eng., Al-Azhar University, Qena, Egypt. \\ 2 Mining and Petroleum Dept., Faculty of Eng., Al-Azhaq2r University, Cairo, Egypt. \\ ${ }^{3}$ Central Metallurgical Research \& Development Institute. Cairo, Egypt.
}

\begin{abstract}
A wastewater of paper industry was treated using two different hydrocyclones $(48 \mathrm{~mm}$, and $73 \mathrm{~mm}$ ) followed by Electro-coagulation (EC) process as a second stage to enhance the treatment process. The effect of design and operating parameters on the separation efficiency was investigated. Separation efficiency of $77 \%$ can be obtained for both hydrocyclones. The treatment process has a great potential to reduce the COD, BOD, TS, TSS, color and turbidity.
\end{abstract}

Key Words: Hydrocyclone; industrial wastewater; Paper industry; wastewater.

\begin{tabular}{|llll|}
\hline \multicolumn{2}{|l|}{ NOMENCLATURE } & & \\
$\mathrm{OF}$ & Overflow product & $\mathrm{E}_{\mathrm{S}}$ & Separation efficiency \\
$\mathrm{UF}$ & Underflow product & $\mathrm{C}_{\mathrm{S}}$ & Feed solid content \\
$\mathrm{D}_{\mathrm{c}}$ & Cyclone diameter & $\mathrm{P}$ & Operating pressure \\
$\mathrm{D}_{\circ}$ & Vortex finder diameter & $\mathrm{Q}_{\mathrm{o} . \mathrm{f}}$ & Overflow flow rate \\
$\mathrm{D}_{\mathrm{i}}$ & Feed inlet diameter & $\mathrm{Q}_{\mathrm{u} . \mathrm{f}}$ & Underflow flow rate \\
$\mathrm{D}_{\mathrm{u}}$ & Underflow diameter & $\mathrm{IWW}$ & Industrial wastewater \\
$\mathrm{H}$ & Cylindrical part length & $\mathrm{COD}$ & Chemical Oxygen Demand \\
$\mathrm{I}$ & Inner vortex finder length & $\mathrm{COD}$ & Biochemical Oxygen Demand \\
$\mathrm{L}$ & Overall length & $\mathrm{TS}$ & Total solids \\
$\theta$ & Cone angle & $\mathrm{TSS}$ & Total suspended solids \\
$\mathrm{V}_{1}$ & Feed inlet pressure control valve & $\mathrm{d}_{50}$ & Cut size \\
$\mathrm{V}_{2}$ & Bypass valve & $\mathrm{P}_{\mathrm{g}}$ & Pressure gauge \\
$\mathrm{B} / \mathrm{P}$ & By pass flow & $E_{C}$ & Electro-coagulation \\
\hline
\end{tabular}

\section{INTRODUCTION}

Environmental pollution from industrial wastewater disposal is one of the most serious environmental issues. It contains complex organic compounds, heavy metals, solvents, dyes, pesticides, etc. In many developing countries more than $70 \%$ of industrial wastewaters are disposed untreated into free surface water [1]. The paper industry is one of the biggest water consumers between all other industries [2,3]. The wastewater obtained from this industry is characterized by large amounts of organic materials, suspended solids, dark color and toxic matters as well as high levels of Biological Oxygen Demand (BOD), Chemical Oxygen Demand (COD) [4]. So, the treatment of paper industry wastewater is inevitable [4]. The treatment of paper industry wastewater is generally treated using physico-chemical and biological methods [5]. Chemical treatment can completely remove the contaminant agents from the paper wastewaters [5]. 
Hydrocyclones have a wide number of applications in the industry, and it considers the most applied separation equipment in current technology. They are used to separate two phases in a liquid medium in different industries like mineral processing [6,7], chemical industry [8], environmental industry [9], sewage treatment [10], food engineering and others [11]. It is employed in liquid clarification, slurry thickening, solids washing [9], liquid degassing, solids classification or sorting based on density or particle shape [8, 12]. The advantages of hydrocyclone include high particulate removal efficiency, a compact treatment facility, relatively low cost, does not require supplementary addition of chemicals, reduces the volume of produced sludge and the possibility of complete automation $[10,13]$. The efficiency of a hydrocyclone depends on its design and operating parameters [14].

The characteristics of the treated water can be enhanced by using electro-coagulation process after the hydrocyclone treatment. Electro-coagulation is an emerging technology that combines the functions and advantages of conventional coagulation, flotation, and electrochemistry in wastewater treatment. Electro-coagulation was studied extensively in the latter half of the 20th century[15]. It has many benefits as compatibility, amenability to automation, cost effectiveness, energy efficiency, safety, and versatility[16]. The electro-coagulation process operates on the base of the principle that the cations produced electrically from iron or aluminum anodes which is responsible for the coagulation of contaminants from an aqueous medium [17]. The flocculated particles attracted by small bubbles of oxygen and hydrogen generated from electrolysis of water. Thus, the flocculated particles float towards the surface[18].

The present work aims to investigate the possibility of using the hydrocyclone as a separation device in treatment of industrial wastewater resulting from Qena Company for paper industry.

\section{MATERIALS AND METHODS}

\subsection{Wastewater sampling and characterization}

A 500 liters sample of an industrial wastewater supplied by Qena Company for paper industry (Qus, Qena, Egypt) was collected from raw basin and stocked in a plastic vessel. It was immediately transported to Central Metallurgical Research and Development Institute, Cairo, Egypt, and stored in a refrigerator at $4{ }^{\circ} \mathrm{C}$ before further analysis. The characteristics of this sample are reported in Table 1.

Table 1: Characterization of raw industrial wastewater (IWW) from Qena Company for paper industry.

\begin{tabular}{lcc}
\hline Parameter & Value & Unit \\
\hline $\mathrm{pH}$ & 6.58 & - \\
BOD5 & 2900 & $\mathrm{mg} / \mathrm{L}$ \\
COD & 650 & $\mathrm{mg} / \mathrm{L}$ \\
Total Solids (TS) & 23590 & $\mathrm{mg} / \mathrm{L}$ \\
Total suspended solids (TSS) & 23294 & $\mathrm{mg} / \mathrm{L}$ \\
Oils and Grease & 45.7 & $\mathrm{mg} / \mathrm{L}$ \\
Sulphides & 10.4 & $\mathrm{mg} / \mathrm{L}$ \\
Phenols & Non & $\mathrm{mg} / \mathrm{L}$ \\
Phosphate & 3.2 & $\mathrm{mg} / \mathrm{L}$ \\
Fe & 7.5 & $\mathrm{mg} / \mathrm{L}$ \\
Turbidity & 498 & $(\mathrm{NTU})$ \\
Color & 36 & $\%$ \\
\hline
\end{tabular}

\subsection{Experimental setup}

The experimental setup involved two different hydrocyclones (48 $\mathrm{mm}$ and $73 \mathrm{~mm}$ ) shown in Fig. $1 \mathrm{a}, \mathrm{b}$ and Electro-coagulation unit shown in Fig 2. The studied design and operating parameters are shown in Tables 2, 3 respectively. 


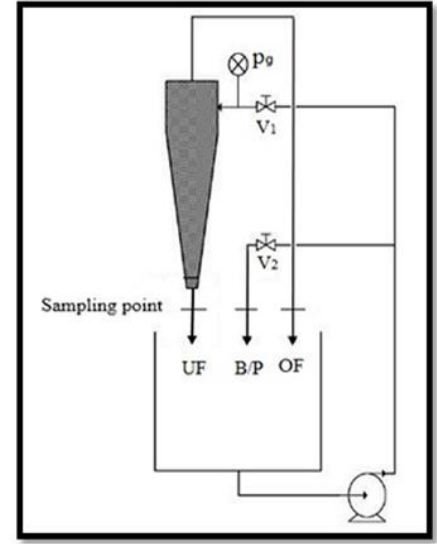

(a)

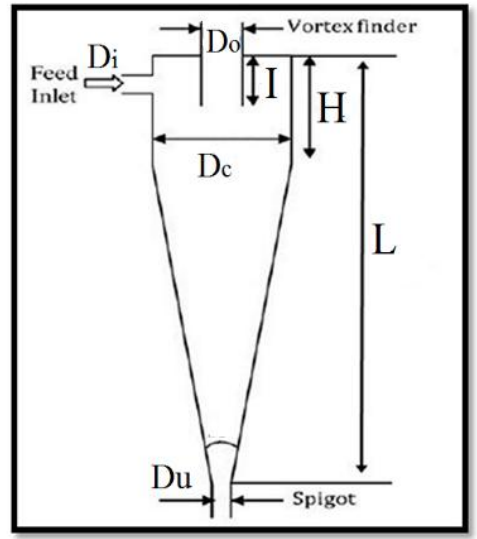

(b)

Fig. 1. (a) Schematic diagram of experimental set-up (b) Hydrocyclone design dimensions (in mm).
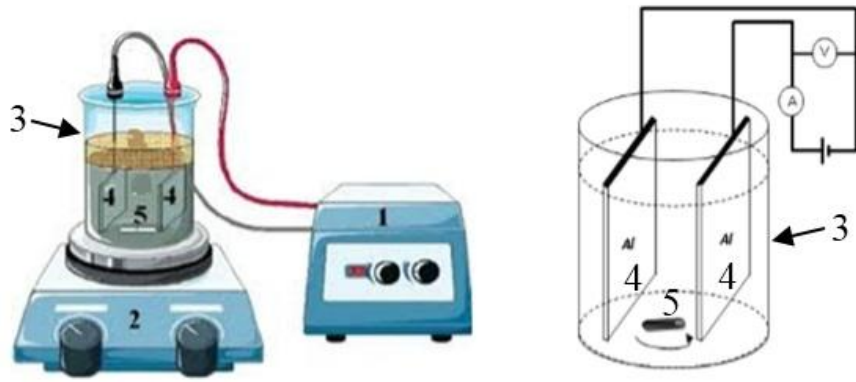

Fig.2. The Electro-coagulation test rig. 1- DC power supply; 2- Magnetic stirrer; 3- Cylindrical glass 400 ml; 4- Aluminum electrodes; 5- A magnetic bar.

Table 2: Design parameters investigated

\begin{tabular}{|c|c|c|}
\hline Design parameters, mm & $D_{C}=48 \mathrm{~mm}$ & $D_{C}=73 \mathrm{~mm}$ \\
\hline Cylindrical part length, $\mathrm{H}$ & 87 & 95 \\
\hline Inlet diameter, $D_{i}$ & $7,8.5,10,12$ & $11,13,15,18$ \\
\hline Vortex finder diameter, $D_{0}$ & $7.5,10,13,16$ & $11,15,20,25$ \\
\hline Underflow diameter, $D_{u}$ & $5,7,9,10$ & $7.5,9,12,15$ \\
\hline Inner vortex finder length, I & 30 & 50 \\
\hline Overall length, $\mathrm{L}$ & 357 & 606 \\
\hline Cone angle, $\theta$ & $14^{\circ}$ & $13^{\circ}$ \\
\hline
\end{tabular}

Table 3: Operating parameters investigated

\begin{tabular}{cc}
\hline Feed solid content $\left(C_{S}\right), \%(w / w)$ & pressure $(\mathbf{P})$, bar \\
\hline $2.3,4,6,8,10$ & $1,2,3,3.5,4.1$ \\
$2.3,4,6,8,10$ & $1,2,3,3.5,4.1$ \\
\hline
\end{tabular}

\subsection{Experimental procedure}

The overflow and underflow flow rates were measured when the system reached steady state. Triplicated samples were collected to record the weight and total volume of products. The samples were then kept in moisture cans and put in an oven at $60^{\circ} \mathrm{C}$ for $24 \mathrm{~h}$ to determine the solid content, mass flow rates and also the water splits in the product streams. The samples were collected in 128 different test conditions.

The overflow steam produced at optimum conditions is fed to the Electro-coagulation unit at operating voltage of $30 \mathrm{~V}$ and at an electric current of 1 Ampere for $10 \mathrm{~min}$. 


\section{RESULTS AND DISCUSSION}

\subsection{Effect of feed inlet pressure (P)}

Figs. 3, 4 show the effect of feed inlet pressure on both the overflow stream content (the water recovery $\%$ and solid $\%$ ) and the separation efficiency $\left({ }_{S}\right)$. From these figures it can be seen that the water recovery $\%$ in overflow stream and the separation efficiency $\left(E_{S}\right)$ increase with increasing the feed inlet pressure, but overflow solid \% decreases. This may be due to the increase of the hydrocyclone throughput and the drag of centrifugal force of the particles toward the wall of hydrocyclone and then to the underflow. At high pressures, relatively more water was discharged through the overflow. On the other hand, the overflow solid \% may decrease due to the decrease in the cut size ${ }^{\left(d_{50}\right)}$ which in turn more solids go through the underflow. The fines in underflow were found to increase by increasing the feed pressure which in turn increases the separation efficiency $\left(E_{S}\right)$. A similar observations were found by $[8,19-21]$.

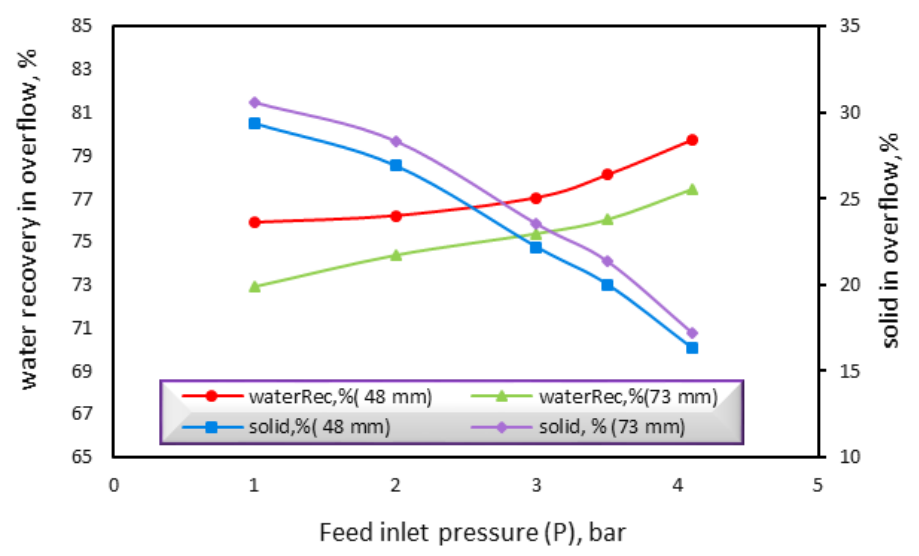

Fig. 3. Effect of feed inlet pressure on the water recovery $\%$ and solid $\%$ in overflow for $48 \mathrm{~mm}$ hydrocyclone at $\left(D_{o}=10 \mathrm{~mm}, D_{u}=10 \mathrm{~mm}, D_{i}=7 \mathrm{~mm}\right)$ and for $73 \mathrm{~mm}$ hydrocyclone at $\left(D_{o}=15 \mathrm{~mm}, D_{u}=15 \mathrm{~mm}, D_{i}=11\right.$ mm).

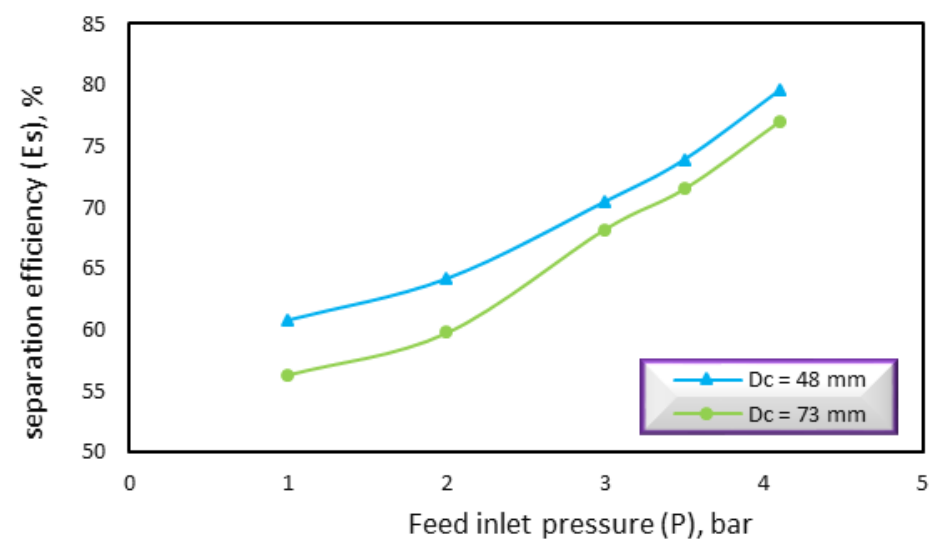

Fig. 4. Effect of feed iplet pressure on the separation efficiency $\left({ }_{S}{ }_{S}, \%\right.$ for $48 \mathrm{~mm}$ hydrocyclone at $\left(D_{o}=10\right.$ $\mathrm{mm}, D_{u}=10 \mathrm{~mm}, D_{i=}=7 \mathrm{~mm}$ ) and for $73 \mathrm{~mm}$ hydrocyclone at $\left.{ }_{o}=15 \mathrm{~mm}, D_{u}=15 \mathrm{~mm}, D_{i=1}=1 \mathrm{~mm}\right)$.

3.2 Effect of feed inlet diameter $\left(D_{i}\right)$

Figs. 5,6 show the effect of feed inlet diameter on both the overflow stream content (the water recovery $\%$ and solid $\%$ ) and on separation efficiency. The results indicate that the overflow water recovery $\%$ and separation efficiency decease by increasing the feed inlet diameter, while overflow solid \% increases. This can be attributed to that the inlet diameter has very little influence on the volume split (S) within the cyclone [21]. By increasing the feed inlet diameter, the inlet velocity was found to decrease which in turn, decrease the tangential velocity and the centrifugal force consequently, the pressure drop decreases, and cut size increases which in turn separation efficiency decreases. 


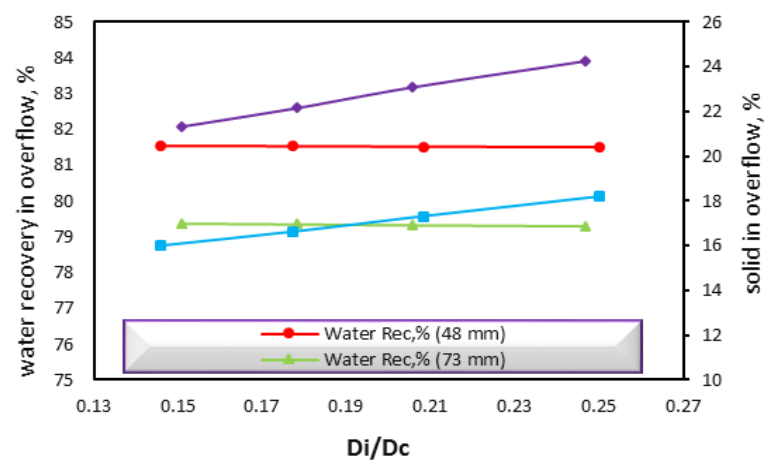

Fig. 5. Effect of feed inlet diameter on the water recovery and solid \% in overflow for $48 \mathrm{~mm}$ hydrocyclone at $\left(P=4.1\right.$ bar, $\left.D_{0}=10 \mathrm{~mm}, \mathrm{Du}=7 \mathrm{~mm}\right)$ and for $73 \mathrm{~mm}$ hydrocyclone at $(P=$ 4.1bar, $D_{0}=15 \mathrm{~mm}$, $\left.D u=9 \mathrm{~mm}\right)$.

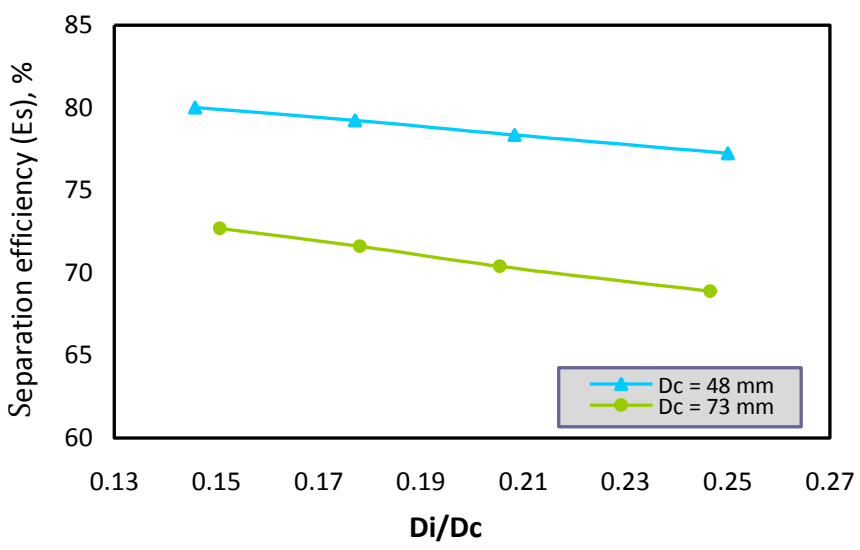

Fig. 6. Effect of feed inlet diameter on the separation efficiency, \% for $48 \mathrm{~mm}$ hydrocyclone at (P $=4.1 \mathrm{bar}, \mathrm{DO}=\mathrm{mm}, \mathrm{Du}=7 \mathrm{~mm})$ and for $73 \mathrm{~mm}$ hydrocyclone at $(P=4.1 \mathrm{bar}, \mathrm{DO}=15 \mathrm{~mm}$,

\subsection{Effect of overflow diameter $\left(D_{o}\right)$}

\section{$\mathrm{Du}=9 \mathrm{~mm})$.}

Fig.7 illustrates the relation between relative overflow diameter $\left(D_{\circ}\right)$ and water recovery as well as solids content in overflow. From this figure, it can be seen that the overflow water recovery and solid $\%$ increase with increasing the overflow diameter. This can be attributed to the increase of the air core diameter by increasing the overflow diameter. The overflow discharge $\left(Q_{O F}\right)$ was found to increase. So, the water recovery $\%$ and solid $\%$ in the overflow stream were found to increase. A similar observations were found by $[12,21]$.

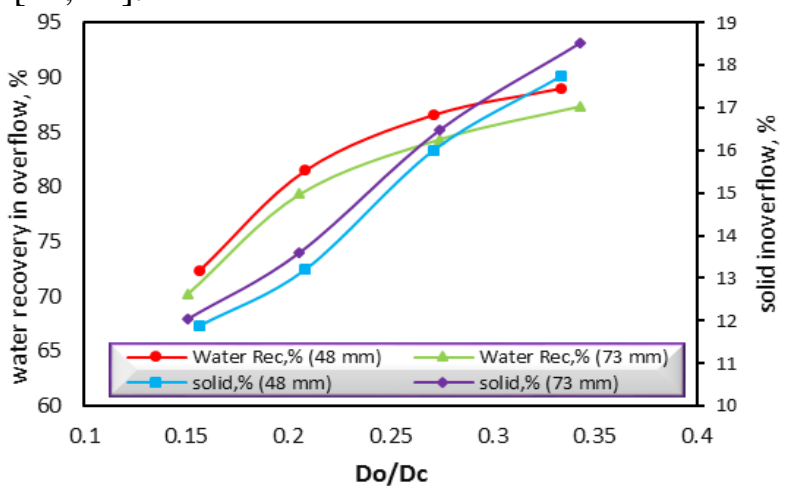

Fig. 7. Effect of overflow diameter on the water recovery and solid \% in overflow for $48 \mathrm{~mm}$ hydrocyclone at $\left(P=4.1 \mathrm{bar}, D_{u}=7 \mathrm{~mm}, D_{i}=7 \mathrm{~mm}\right)$ and for $73 \mathrm{~mm}$ hydrocyclone at $\left(P=4.1\right.$ bar, $\left.D_{u}=9 \mathrm{~mm}, D_{i}=11 \mathrm{~mm}\right)$. 
From Fig. 8, it can be seen that the separation efficiency decreases by increasing the overflow diameter $\left(D_{o}\right)$. This may be due to the increase of the vortex-finder diameter which led to an increase of the number of particles carried upward which in turn, increases the cut size diameter $\left(d_{50}\right)$. By increasing the overflow diameter, the volume split $\left(Q_{O . F} / Q_{U F}\right)$ increases which means that more suspension is discharged through the overflow and less suspension is discharged to the underflow. Consequently the cut size $\left(d_{50}\right)$ increases which reflects the observed decrease in separation efficiency.

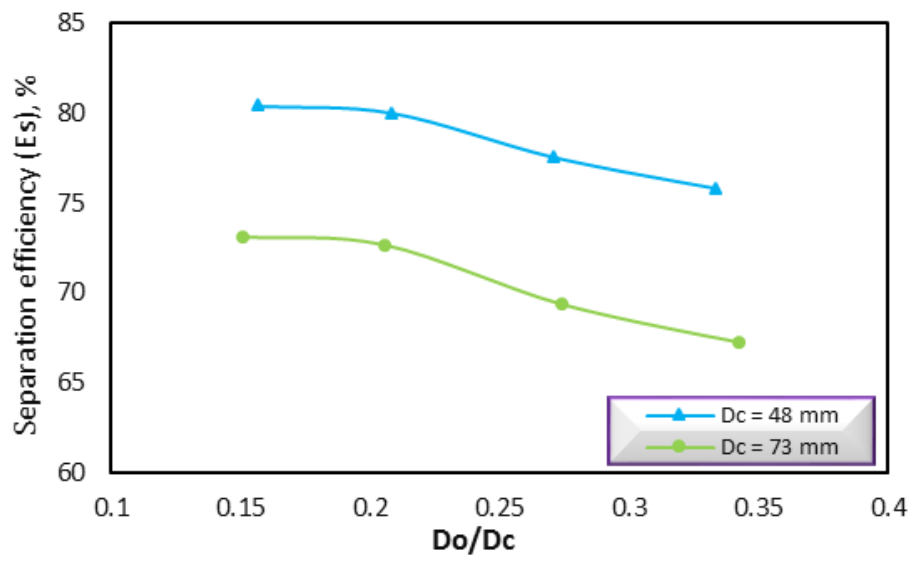

Fig. 8. Effect of overflow diameter on the separation efficiency $\left({ }^{E_{S}}\right), \%$ for $48 \mathrm{~mm}$ hydrocyclone at $(\mathrm{P}=4.1$ bar, $\left.D_{u}=7 \mathrm{~mm}, D_{i}=7 \mathrm{~mm}\right)$ for $73 \mathrm{~mm}$ hydrocyclone at $\left(P=4.1\right.$ bar, $\left.D_{u}=9 \mathrm{~mm}, D_{i}=11 \mathrm{~mm}\right)$.

\subsection{Effect of underflow diameter $\left(D_{u}\right)$}

From Fig. 9, it can be seen that the water recovery \% and solid \% from the feed to overflow stream decrease with increasing the underflow diameter. This can be explained by the fact that the air core diameter is constant as the overflow diameter is kept constant. By increasing the underflow diameter $\left(D_{w}\right)$, the underflow discharge increases. Thus, the overflow discharge decreases which in turn, decrease the water recovery $\%$ and the solid \% in overflow stream.

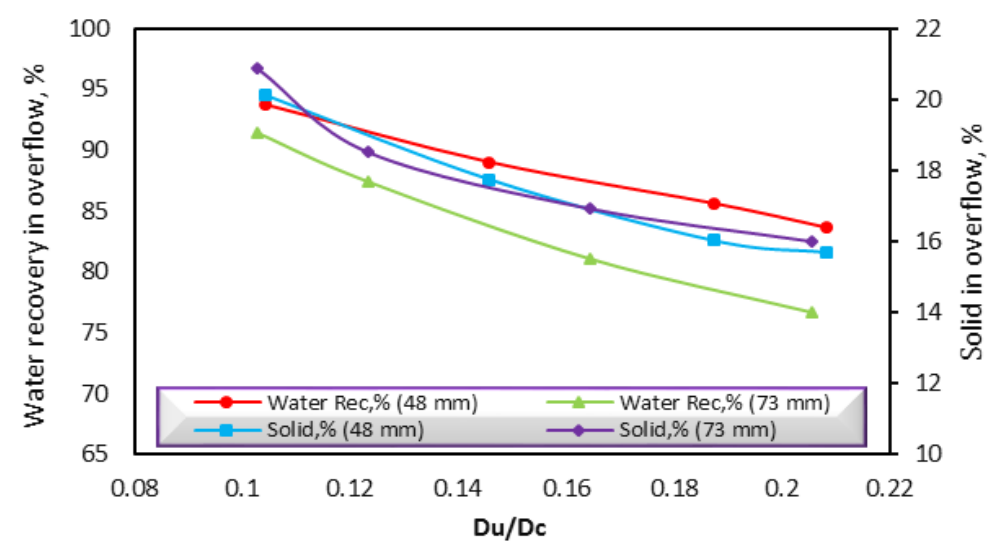

Fig. 9. Effect of underflow diameter on the water recovery and solid \% in overflow for $\mathbf{4 8} \mathbf{m m}$ hydrocyclone at $\left(\mathrm{P}=4.1 \mathrm{bar}, D_{u}=16 \mathrm{~mm}, D_{i}=7 \mathrm{~mm}\right)$ and for $73 \mathrm{~mm}$ hydrocyclone at ( $\mathbf{P}=4.1$ bar, $\left.D_{u}=25 \mathrm{~mm},{ }_{i}=11 \mathrm{~mm}\right)$. 


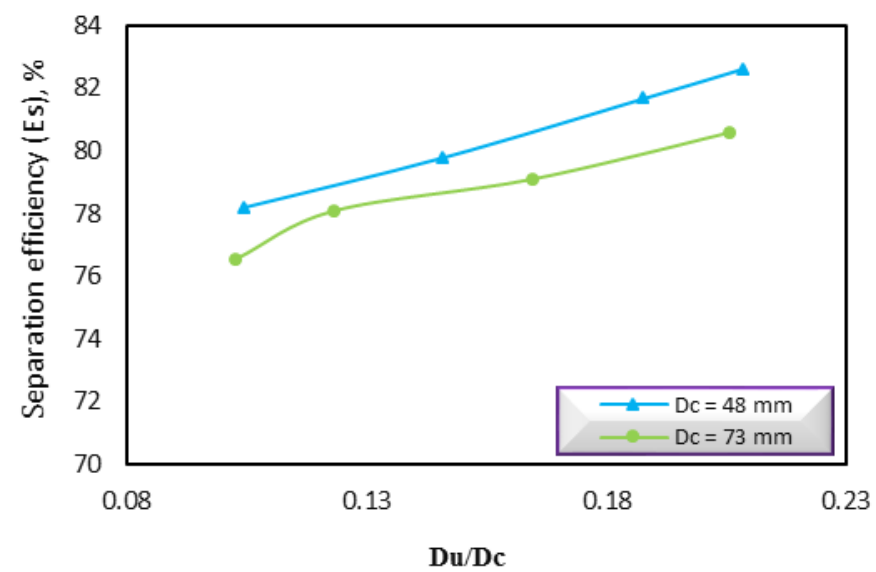

Fig. 10. Effect of underflow diameter on the separation efficiency $\left({ }^{E_{S}}\right), \%$ for $48 \mathrm{~mm}$ hydrocyclone at $(\mathrm{P}=4.1$ bar, $\left.D_{u}=16 \mathrm{~mm}, D_{i}=7 \mathrm{~mm}\right)$ and for $73 \mathrm{~mm}$ hydrocyclone at $\left(P=4.1\right.$ bar, $\left.D_{u}=25 \mathrm{~mm}, D_{i}=11 \mathrm{~mm}\right)$.

It may be observed from figure 10 that the separation efficiency increases with increasing the underflow diameter $\left(D_{w}\right)$. This may be due to the increase of the discharge capacity of the apex. This may be lead to more water go through the underflow with more fine particles. It well known that the cut size $\left(d_{50}\right)$ is inversely proportional to the underflow diameter $\left(D_{w}\right)$, so, the separation efficiency $\left(E_{S}\right)$ was found to increase by increasing the underflow diameter $\left(D_{w}\right)$. A similar observations were reported by $[9,22]$.

\subsection{Effect of feed solid content $\left(c_{s}\right)$}

It is observed that from figures. 11 and 12 , the overflow water recovery and separation efficiency decrease by increasing the feed solid content. On the other hand, the overflow solid \% was found to increase. At higher feed solid concentration, particles' hindered settling condition prevails which does not conform to the Stokes' law and gravity force dominate the exit velocity profile. In dense flow separation (high solid content), more solids are stored in the conical part of the hydrocyclone and they are partially forced to the overflow. More water go through underflow. Hance, water recovery in overflow will be gradually decrease by increasing the feed solid content. Which in turn, reduces solids recovery in the underflow product [12].

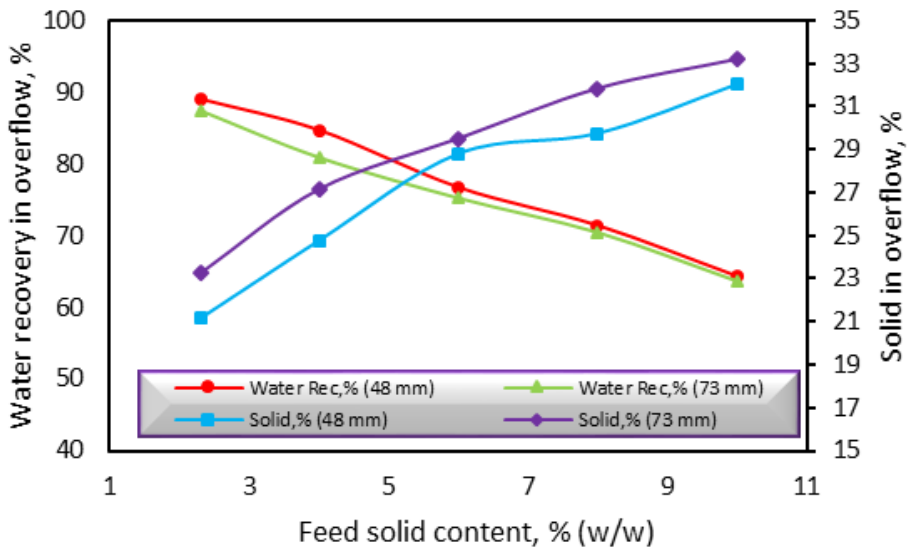

Fig. 11. Effect of feed solid content on the water recovery and solid \% in overflow for $\mathbf{4 8} \mathrm{mm}$ hydrocyclone at $\left(P=4.1\right.$ bar, ${ }_{o}=16 \mathrm{~mm}, D_{u}=7 \mathrm{~mm}$ and $\left.D_{i}=7 \mathrm{~mm}\right)$ and for $73 \mathrm{~mm}$ hydrocyclone at $\left(P=4.1\right.$ bar, ${ }_{o}=25$ $\mathrm{mm}, D_{u}=9 \mathrm{~mm}$ and $\left.D_{i}=11 \mathrm{~mm}\right)$. 


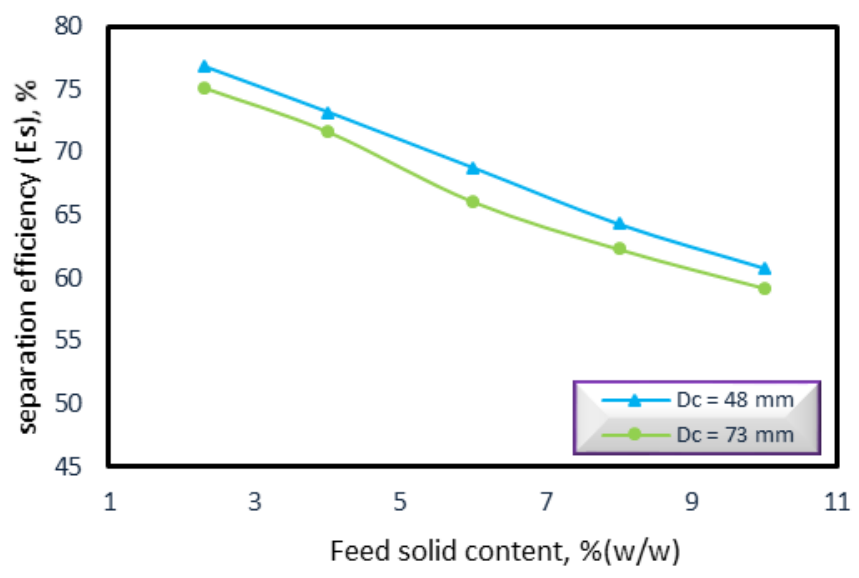

Fig. 12. Effect of feed solid content on the separation efficiency for $48 \mathrm{~mm}$ hydrocyclone at $\left(\mathrm{P}=4.1 \mathrm{bar}, D_{0}=\right.$ $16 \mathrm{~mm}, D_{u}=7 \mathrm{~mm}$ and $\left.D_{i}=7 \mathrm{~mm}\right)$ and for $73 \mathrm{~mm}$ hydrocyclone at $\left(P=4.1\right.$ bar, $D_{o}=25 \mathrm{~mm}, D_{u}=9 \mathrm{~mm}$ and $D_{i}=11 \mathrm{~mm}$ ).

Based on the previous discussed results, the optimum conditions of the wastewater treatment process resulting from paper industry were obtained by using the $48 \mathrm{~mm}$ and $73 \mathrm{~mm}$ hydrocyclones as shown in Table 4 .

Table 5, shows the Percentage of water recovery and solid in overflow and the separation efficiency at the optimum operating conditions.

Table 4: The optimum conditions of the treatment process were obtained by using $t$ he $48 \mathrm{~mm}$ and $73 \mathrm{~mm}$ hydrocyclones

\begin{tabular}{|c|c|c|}
\hline Parameters & $D_{c}=48 \mathrm{~mm}$ & $D_{c}=73 \mathrm{~mm}$ \\
\hline Inlet diameter, $D_{i,}, m m$ & 7 & 11 \\
\hline Vortex finder diameter, $D_{0}, \mathrm{~mm}$ & 16 & 25 \\
\hline Underflow diameter, $D_{W^{s}} m m$ & 7 & 9 \\
\hline Feed pressure, $\mathrm{P}$, bar & 4.1 & 4.1 \\
\hline Feed solid content, $C_{S} \%$ & 2.3 & 2.3 \\
\hline
\end{tabular}

Table 5: Percentage of water recovery and solid \% in overflow and the separation efficiency at the optimum operating conditions of both $48 \mathrm{~mm}$ and $73 \mathrm{~mm}$ hydrocyclones

\begin{tabular}{lcc}
\hline Parameters & $D_{C}=\mathbf{4 8} \mathbf{~ m m}$ & $D_{C}=\mathbf{7 3 ~} \mathbf{~ m m}$ \\
\hline Overflow water recovery & 89 & 87.4 \\
Overflow solid \% & 21.15 & 23.29 \\
Separation efficiency $\left(E_{S}\right)$ & 76.80 & 75.07 \\
\hline
\end{tabular}

From Table 5, there is no large difference between the results of the two hydrocyclones.

\subsection{Electro-coagulation process}

In order to enhance the treatment process of paper industry wastewater the Electro-coagulation process after the hydrocyclone unit was applied. The overflow stream which produced by both 48 $\mathrm{mm}$ and $73 \mathrm{~mm}$ hydrocyclones at optimum conditions is fed to the Electro-coagulation unit at operating voltage of $30 \mathrm{~V}$ and at an electric current of 1 Ampere for $10 \mathrm{~min}$ [23].

Table 6 , shows the characteristics of the paper industry wastewater before and after the treatment process using the $48 \mathrm{~mm}$ and $73 \mathrm{~mm}$ hydrocyclones and Electro-coagulation process. From this table, it can be easily observed that the treatment process has a great potential to reduce the COD, BOD, TS, TSS, color and turbidity. 
Table 6: Characteristics of paper industry wastewater before and after treatment hydrocyclone and Electro-coagulation (EC) for both 48 and $73 \mathrm{~mm}$ hydrocyclones.

\begin{tabular}{|c|c|c|c|c|c|}
\hline \multirow[b]{2}{*}{ Parameters } & \multirow[b]{2}{*}{$\begin{array}{c}\text { Raw } \\
\text { IWW }\end{array}$} & \multicolumn{2}{|c|}{$48 \mathrm{~mm}$ hydrocyclone } & \multicolumn{2}{|c|}{$73 \mathrm{~mm}$ hydrocyclone } \\
\hline & & $\begin{array}{l}\text { After treatment by } \\
\quad 48 \mathrm{~mm} \\
\text { hydrocyclone only }\end{array}$ & $\begin{array}{l}\text { After treatment by } \\
48 \mathrm{~mm} \\
\text { hydrocyclone and } \\
\text { Ec }\end{array}$ & $\begin{array}{c}\text { After treatment by } \\
73 \mathrm{~mm} \\
\text { hydrocyclone only }\end{array}$ & $\begin{array}{c}\text { After } \\
\text { treatment by } \\
73 \mathrm{~mm} \\
\text { hydrocyclone } \\
\text { and Ec }\end{array}$ \\
\hline PH & 6.58 & 6.65 & 7.6 & 6.62 & 7.6 \\
\hline BOD, (mg/L) & 2900 & 110 & 10 & 120 & 15 \\
\hline COD, $(\mathrm{mg} / \mathrm{L})$ & 650 & 121 & 12 & 131 & 19 \\
\hline $\mathrm{TS},(\mathrm{mg} / \mathrm{L})$ & 2359 & 434 & 39 & 443 & 43 \\
\hline TSS, (mg/L) & 2329 & 394 & 23 & 409 & 29 \\
\hline Oils and Grease, & 45.7 & 3.2 & 0.4 & 4.1 & 0.6 \\
\hline Sulfides, (mg/L) & 10.4 & 5.9 & 0.32 & 5.9 & 0.32 \\
\hline Phenols, (mg/L) & Non & Non & Non & Non & Non \\
\hline Phosphate, (mg/L) & 3.2 & 1.2 & 0.2 & 1.2 & 0.2 \\
\hline $\mathrm{Fe},(\mathrm{mg} / \mathrm{L})$ & 7.5 & 0.7 & 0.3 & 0.8 & 0.3 \\
\hline Turbidity, (NTU) & 498 & 87 & 19 & 93 & 19 \\
\hline Color, \% & 36 & 10 & 3 & 12 & 3 \\
\hline
\end{tabular}

\section{Conclusions}

In this study, the hydrocyclone was used to treat the paper industry wastewater. The experiments were carried out using two different hydrocyclones $(48 \mathrm{~mm}$, and $73 \mathrm{~mm}$ ) followed by Electrocoagulation process as a second stage to enhance the treatment process. The effect of design and operating parameters on hydrocyclone performance and separation efficiency was investigated. The results showed that the hydrocyclone was found to be very effective to treat the paper industry wastewater. The characteristics of the treated water were highly enhanced by using electro-coagulation process after the hydrocyclone treatment. The optimum conditions which achieved the maximum water recovery with minimum solid recovery in overflow stream of two hydrocyclones were found to be as follows:

a) The hydrocyclone $48 \mathrm{~mm}$ : feed pressure $(\mathrm{P})=4.1$ bar, feed inlet diameter $\left(D_{i}\right)=7 \mathrm{~mm}$, overflow diameter $\left(D_{\diamond}\right)=16 \mathrm{~mm}$, underflow diameter $\left(D_{u}\right)=7 \mathrm{~mm}$, feed solid content $\left(c_{s}\right)=2.3 \%$.

b) The hydrocyclone $73 \mathrm{~mm}$ : feed pressure $(\mathrm{P})=4.1 \mathrm{bar}$, feed inlet diameter $\left(D_{i}\right)=11 \mathrm{~mm}$, overflow diameter $\left(D_{o}\right)=25 \mathrm{~mm}$, underflow diameter $\left(D_{u}\right)=9 \mathrm{~mm}$, feed solid content $\left(c_{s}\right)=2.3 \%$.

Chemical analysis of the final treated wastewater showed that the treatment process using $48 \mathrm{~mm}$ and $73 \mathrm{~mm}$ hydrocyclones followed by Electro-coagulation (EC) process as a second stage has efficiently reduced the COD, BOD, TS, TSS, color and turbidity.

\section{REFERENCES}

[1] U. Water, "The United Nations World Water Development Report 3-Water in a Changing World," United Nations Educational Scientific and Cultural Organization, Paris, 2009.

[2] K. Eskelinen, H. Särkkä, T. A. Kurniawan, and M. E. Sillanpää, "Removal of recalcitrant contaminants from bleaching effluents in pulp and paper mills using ultrasonic irradiation and Fenton-like oxidation, electrochemical treatment, and/or chemical precipitation: a comparative study," Desalination, vol. 255, pp. 179-187, 2010.

[3] D. Pokhrel and T. Viraraghavan, "Treatment of pulp and paper mill wastewater-a review," Science of the total environment, vol. 333, pp. 37-58, 2004.

[4] Z. Beril Gönder, S. Arayici, and H. Barlas, "Advanced treatment of pulp and paper mill wastewater by nanofiltration process: Effects of operating conditions on membrane fouling," Separation and Purification Technology Separation and Purification Technology, vol. 76, pp. 292-302, 2011.

[5] N. Jaafarzadeh, F. Ghanbari, M. Ahmadi, and M. Omidinasab, "Efficient integrated processes for pulp and paper wastewater treatment and phytotoxicity reduction: permanganate, 
TREATMENT OF PAPER INDUSTRY WASTEWATER

electro-fenton and Co 3 O 4/UV/peroxymonosulfate," Chemical Engineering Journal, vol. 308, pp. 142-150, 2017.

[6] V. Golyk, S. Huber, M. Farghaly, G. Prölss, E. Endres, T. Neesse, and M. Hararah, "Higher kaolin recovery with a water-injection cyclone," Minerals Engineering, vol. 24, pp. 98$101,2011$.

[7] S. Mohanty and B. Das, "Optimization Studies of Hydrocyclone for Beneficiation of Iron Ore Slimes," Mineral Processing and Extractive Metallurgy Review, vol. 31, pp. 86-96, 2010.

[8] T. Neesse, J. Dueck, H. Schwemmer, and M. Farghaly, "Using a high pressure hydrocyclone for solids classification in the submicron range," Minerals Engineering, vol. 71, pp. 85-88, 2015.

[9] M. Farghaly, V. Golyk, G. Ibrahim, M. Ahmed, and T. Neesse, "Controlled wash water injection to the hydrocyclone underflow," Minerals Engineering, vol. 23, pp. 321-325, 2010 .

[10] Q. Yang, Z.-m. Li, W.-j. Lv, and H.-l. Wang, "On the laboratory and field studies of removing fine particles suspended in wastewater using mini-hydrocyclone," Separation and Purification Technology, vol. 110, pp. 93-100, 2013.

[11] J. Dueck, E. Pikushchak, L. Minkov, M. Farghaly, and T. Neesse, "Mechanism of hydrocyclone separation with water injection," Minerals Engineering, vol. 23, pp. 289-294, 2010.

[12] M. M. Ahmed, G. A. Ibrahim, and M. G. Farghaly, "Performance of a three-product hydrocyclone," International Journal of Mineral Processing, vol. 91, pp. 34-40, 2009.

[13] M. Mansour-Geoffrion, P. L. Dold, D. Lamarre, A. Gadbois, S. Deleris, and Y. Comeau, "Characterizing hydrocyclone performance for grit removal from wastewater treatment activated sludge plants," Minerals Engineering, vol. 23, pp. 359-364, 2010.

[14] B. A. Wills and J. Finch, Wills' mineral processing technology: an introduction to the practical aspects of ore treatment and mineral recovery, 7th ed.Butterworth-Heinemann, 2006, $212-223$.

[15] A. A. Normann, "Electrocoagulation for treatment of tunnel wash water: a proof of concept; Master's Thesis 2017," 30 ECTS Faculty of science and technology, Norwegian University of Life Sciences, 2017.

[16] B. K. Nandi and S. Patel, "Effects of operational parameters on the removal of brilliant green dye from aqueous solutions by electrocoagulation," Arabian Journal of Chemistry, vol. 10, pp. S2961-S2968, 2017.

[17] S. I. Chaturvedi, "Electro-coagulation: a novel wastewater treatment method," International Journal of Modern Engineering Research, vol. 3, pp. 93-100, 2013.

[18] O. Sahu, B. Mazumdar, and P. Chaudhari, "Treatment of wastewater by electrocoagulation: a review," Environmental Science and Pollution Research, vol. 21, pp. 2397-2413, 2014.

[19] H. G. Papacharalambous and S.-C. Sun, "CYCLONE CLASSIFICATION OF ARTIFICIAL ABRASIVE POWDERS," Transactions of the American Institute of Mining, Metallurgical and Petroleum Engineers, vol. 226, p. 461, 1963.

[20] C. Huang, J.-g. Wang, J.-y. Wang, C. Chen, and H.-1. Wang, "Pressure drop and flow distribution in a mini-hydrocyclone group: UU-type parallel arrangement," Separation and Purification Technology, vol. 103, pp. 139-150, 2013.

[21] R. Sabbagh, M. G. Lipsett, C. R. Koch, and D. S. Nobes, "Predicting equivalent settling area factor in hydrocyclones; a method for determining tangential velocity profile," Separation and Purification Technology, vol. 163, pp. 341-351, 2016.

[22] N. K. Silva, D. O. Silva, L. G. Vieira, and M. A. Barrozo, "Effects of underflow diameter and vortex finder length on the performance of a newly designed filtering hydrocyclone," Powder Technology, vol. 286, pp. 305-310, 2015.

[23] A. Khalek, F. El-Hosiny, K. Selim, and I. Osama, "Produced Water Treatment Using a New Designed Electroflotation Cell," International Journal of Research in Industrial Engineering, vol. 6, pp. 328-338, 2017. 